\title{
STABILITY INDICATING REVERSE-PHASE HIGH- PERFORMANCE LIQUID CHROMATOGRAPHY METHOD DEVELOPMENT AND VALIDATION FOR SIMULTANEOUS ESTIMATION OF TELMISARTAN AND BENIDIPINE HYDROCHLORIDE IN PHARMACEUTICAL DOSAGE FORM
}

\author{
MAJAN NAIM ${ }^{1 *}$, AEJAZ AHMED ${ }^{1}$, KHAN GJ $^{2}$ \\ ${ }^{1}$ Department of Pharmaceutical Chemistry, Ali-Allana College of Pharmacy, Akkalkuwa, Nandurbar, Maharashtra, India. ${ }^{2}$ Department of \\ Pharmacology, Ali-Allana College of Pharmacy, Akkalkuwa, Nandurbar, Maharashtra, India. Email: naimmajan@gmail.com
}

Received: 06 January 2018, Revised and Accepted: 12 February 2018

ABSTRACT

Objective: Development and validation of stability indicating reverse-phase high- performance liquid chromatography (RP-HPLC) method for simultaneous estimation of telmisartan (TEL) and benidipine hydrochloride (BND) in pharmaceutical dosage form.

Methods: Reverse phase chromatography was selected because of its suggested use for ionic and moderate to non-polar compounds. Reverse phase chromatography is simple, suitable, better regarding efficiency, stability, and reproducibility. $\mathrm{C}_{18}$ column, a $250 \times 4.6$ mm column of $5.0 \mu \mathrm{m}$ particle packing, was selected for separation of TEL and BND. Different solvent systems were tried and optimized in combinations as mobile phase. TEL $(40 \mu \mathrm{g} / \mathrm{ml})$ and BND ( $4 \mu \mathrm{g} / \mathrm{ml})$ in buffer, $\mathrm{pH}$ 4.0: Methanol (50:50) was developed as it was showing good peak shapes and a significant amount of resolution. The mobile phase was flowed at $1.0 \mathrm{ml} / \mathrm{min}$ with detection of both the analytes at $210 \mathrm{~nm}$ using photodiode array detector.

Result: Development of method was done, and validation was accomplished using specificity, linearity, accuracy, precision, robustness, limit of detection, and limit of quantitation. The method was found linear from 20 to $60 \mu \mathrm{g} / \mathrm{ml}$ and $2-6 \mu \mathrm{g} / \mathrm{ml}$ for TEL and BND individually. The percentage recoveries of TEL $100.46 \%$ and BND100.08\% were, respectively.

Conclusion: This stability indicating RP-HPLC methods were developed by degradation of sample and compared with standard. The percentage relative standard deviation was also $<2 \%$ showing high degree of precision of the proposed method. The proposed method can be used for routine analysis of benidipine $\mathrm{HCl}$ and TEL in combined dosage form and quality control in bulk manufacturing.

Keywords: Telmisartan, Benidipine, Reverse-phase high- performance liquid chromatography, Stability indicating method.

(C) 2018 The Authors. Published by Innovare Academic Sciences Pvt Ltd. This is an open access article under the CC BY license (http://creativecommons. org/licenses/by/4. 0/) DOI: http://dx.doi.org/10.22159/ajpcr.2018.v11i5.24651

\section{INTRODUCTION}

Telmisartan (TEL) IUPAC name 2-(4-\{[4-methyl-6-(1-methyl-1H-1,3benzodiazol-2-yl)-2-propyl-1H-1,3-benzodiazol-1-yl]methyl\}phenyl) benzoic acid show Fig. 1. TEL is a diabetes angiotensin receptor blocker that shows high affinity for the angiotensin II type 1 (AT1) receptors, has a long duration of action, and has the longest half-life of any angiotensin II receptor blocker (ARB). In clinical studies, TEL shows comparable antihypertensive activity to other major antihypertensive classes, such as angiotensin-converting enzyme (ACE) inhibitors, beta-blockers, and calcium antagonists [1-2]. Benidipine HCL IUPAC name 3-(3R)-1benzylpiperidin-3-yl 5-methyl (4R)-2,6-dimethyl-4-(3-nitrophenyl)1,4-dihydropyridine-3,5-dicarboxylates show Fig. 2. Benidipine hydrochloride (BEN) is a highly potent and long-acting dihydropyridine (DHP) calcium channel blocker (L, N, and T-type) and orally active antianginal, antihypertensive agent which displace a wide range of activities in vitro and in vivo. It is a single enantiomers dihydropyridine calcium channel blocker for the treatment of hypertension. It has also been shown to have anti-obesity activity. It inhibits not only L-type but also T-type calcium channels [3-4]. Several studies were reported for both drugs individually using different analytical procedures for TEL like reverse-phase high-performance liquid chromatography (RP-HPLC) [5-8], potentiometry titration, Stability indicating RP-HPLC, [9,10] UV (ultraviolet)-visible spectroscopy, [11,12] absorption correction method,[13] simultaneous equation method [14] while for benidipine HPLC/UPLC,[15] UV-visible spectroscopy, etc., were available [16,17].

UTH healthcare has introduced novel fixed-dose combination (FDC) of both the examining drugs commercially as tablet formulation. Literatures resulted in the getting of few methods for this FDC product; however, no stability indicating HPLC method was found. To get simple, rapid, accurate, and economic, it was tried to develop and validate RPHPLC method with stability indicating properties of FDC's TEL and benidipine in commercial preparations. The addition of this analytical methods in the current practice would help the pharmaceutical industries in large to preserve the excellence of their products containing these active ingredients and also the enforcement agencies in general to monitor the quality of the marketed products.

\section{METHODS}

Standard of TEL and benidipine were obtained from Yash Pharmaceuticals Ahmadabad. Tel-Benina ${ }^{\circledR}$ (UTH Healthcare) tablets were purchased from the local medical store. TEL $40 \mathrm{mg}$ and benidipine $4 \mathrm{mg}$ were used.

\section{TEL standard stock solution $(400 \mu \mathrm{g} / \mathrm{ml})$}

A sample of $40 \mathrm{mg}$ of TEL was weighed and transferred to a $100 \mathrm{ml}$ volumetric flask. Volume was made up to the mark with methanol.

Benidipine hydrochloride (BND) standard stock solution ( $40 \mu \mathrm{g} / \mathrm{ml}$ ) A sample of $40 \mathrm{mg}$ of BND was weighed and transferred to a $100 \mathrm{ml}$ volumetric flask. Volume was made up to the mark with methanol, take $10 \mathrm{ml}$ from this solution, and transfer to $100 \mathrm{ml}$ volumetric flask and volume was made up with methanol.

Preparation of standard solution of binary mixtures of TEL $(40 \mu \mathrm{g} / \mathrm{ml})$ and BND $(4 \mu \mathrm{g} / \mathrm{ml})$

Take $1 \mathrm{ml}$ from the TEL stock solution and $1 \mathrm{ml}$ from BND stock solution and transferred to $10 \mathrm{ml}$ volumetric flask and volume made up to the mark by mobile phase which was used in particular trials. 
Method validation [18-23]

Linearity

The linearity for TEL and BND were assessed by analysis of combined standard solution in range of $20-60 \mu \mathrm{g} / \mathrm{ml}$ and $2-6 \mu \mathrm{g} / \mathrm{ml}$, respectively, $5,7.5,10,12.5$, and $15 \mathrm{ml}$ solutions were pipette out from the stock solution of TEL ( $400 \mu \mathrm{g} / \mathrm{ml})$ and BND ( $40 \mu \mathrm{g} / \mathrm{ml})$ and transfer to $100 \mathrm{ml}$ volumetric flask and make up with mobile phase to obtain $20,30,40,50$, and $60 \mu \mathrm{g} / \mathrm{ml}$ and $2,3,4,5$, and $6 \mu \mathrm{g} / \mathrm{ml}$ for TEL and BND, respectively.

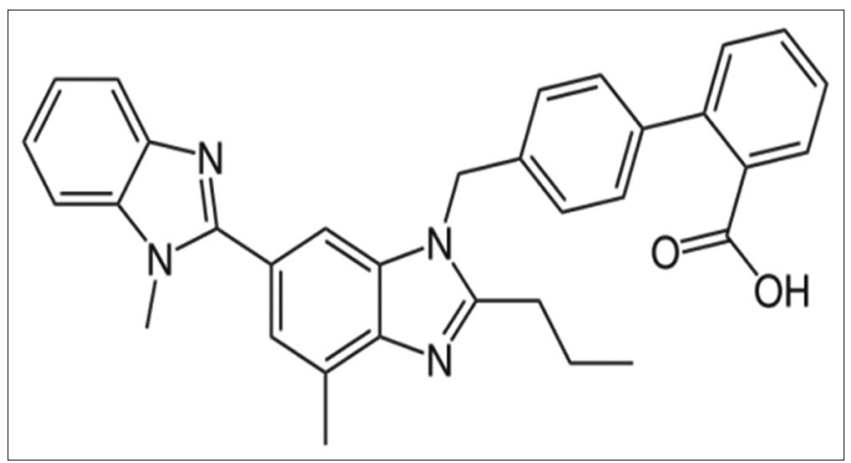

Fig. 1: Structure of telmisartan

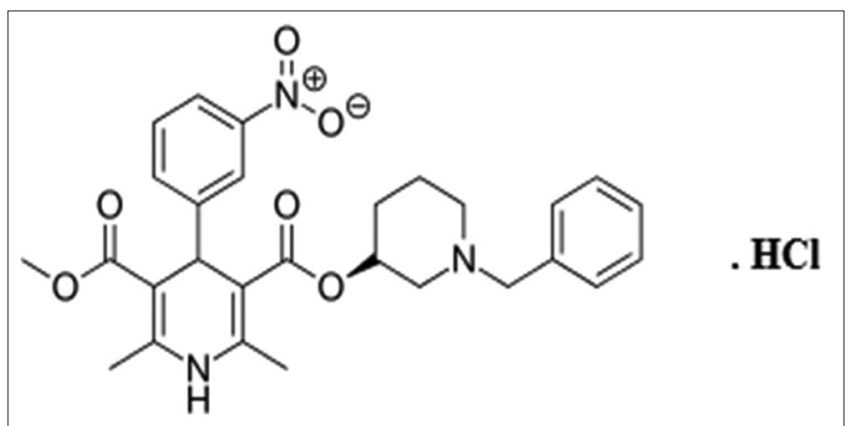

Fig. 2: Structure of benidipine hydrochloride

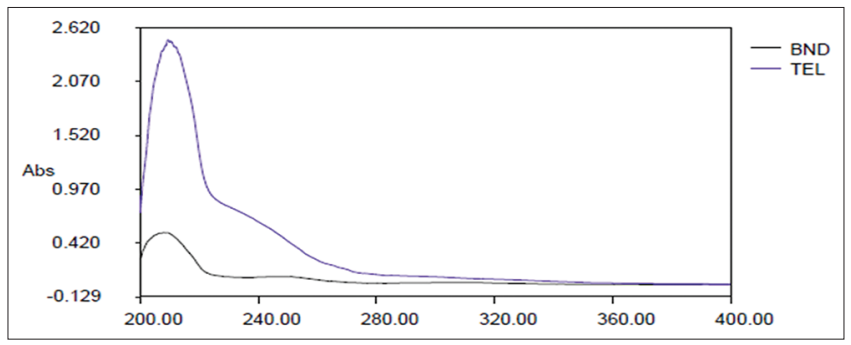

Fig. 3: Overlay ultraviolet spectrum of telmisartan and benidipine hydrochloride

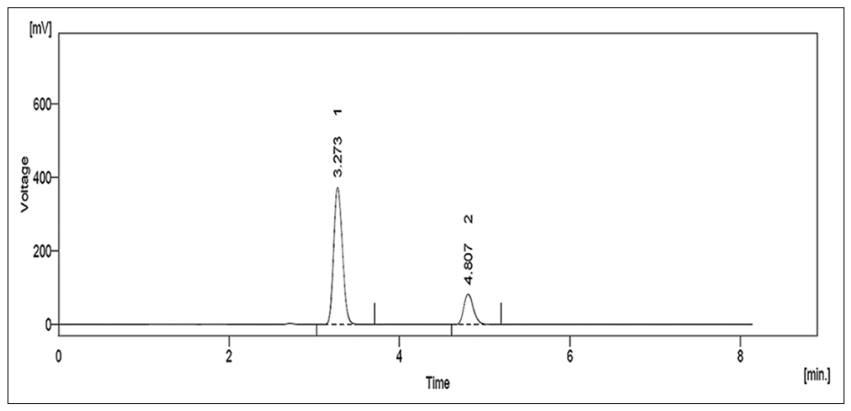

Fig. 4: Chromatogram of telmisartan and benidipine hydrochloride
Precision

Results should be expressed as relative standard deviation (RSD) or coefficient of variance. In repeatability standard solution containing TEL $(40 \mu \mathrm{g} / \mathrm{ml})$ and BND ( $4 \mu \mathrm{g} / \mathrm{ml})$ was injected six times and areas of peaks were measured and \% RSD was calculated. After

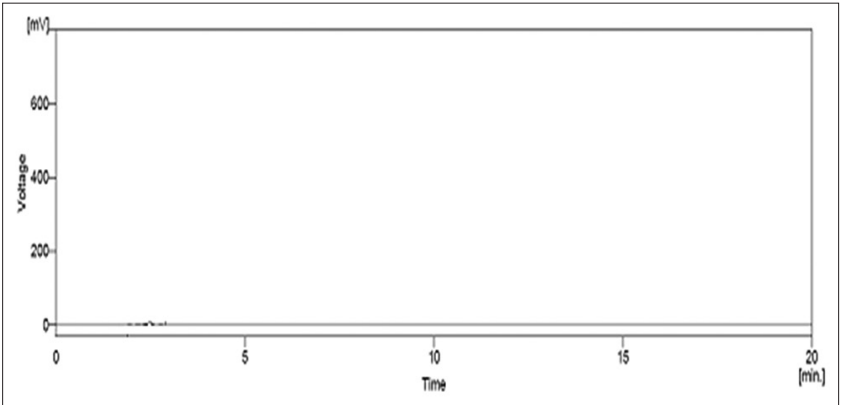

Fig. 5: Chromatogram of benidipine hydrochloride and telmisartan blank

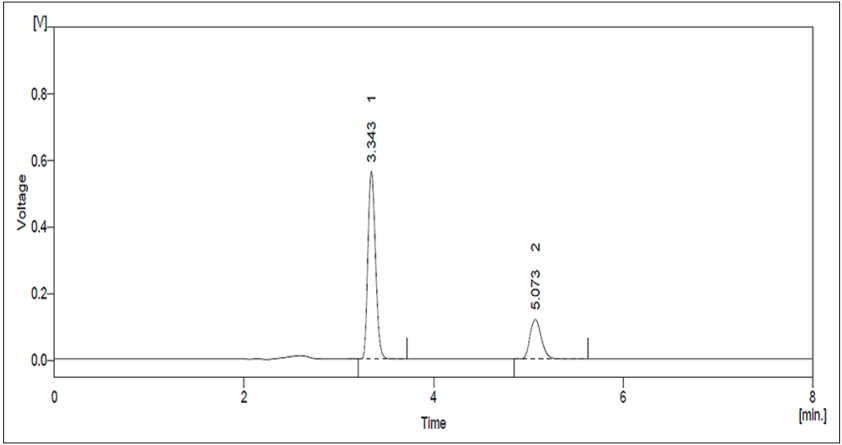

Fig. 6: Chromatogram of benidipine hydrochloride and telmisartan standard

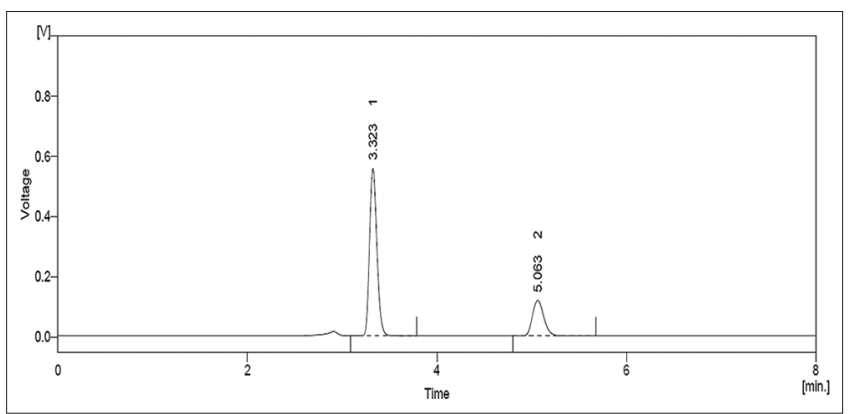

Fig. 7: Chromatogram of Benidipine hydrochloride and telmisartan sample

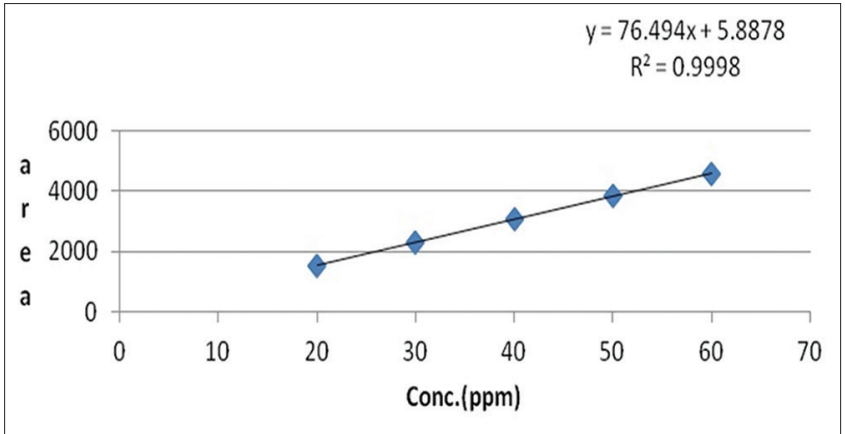

Fig. 8: Calibration curve of telmisartan 
that in intraday precision standard solution containing $(20,40$, and $60 \mu \mathrm{g} / \mathrm{ml})$ of TEL and $(2,4$, and $6 \mu \mathrm{g} / \mathrm{ml})$ of BND were analyzed three times on the same day and percentage RSD was calculated. In the last inter-day precision was done by making standard solution containing $(20,40$, and $60 \mu \mathrm{g} / \mathrm{ml})$ of TEL and $(2,4$, and $6 \mu \mathrm{g} / \mathrm{ml})$ of BND were analyzed three times on the different day and percentage RSD was calculated.

\section{Accuracy}

TEL20 $\mu \mathrm{g} / \mathrm{ml}$ and BND2 $\mu \mathrm{g} / \mathrm{ml}$ drug solution were taken in three different flask label A, B, and C. Spiked $80 \%, 100 \%$, and $120 \%$ of standard solution in it and diluted up to $10 \mathrm{ml}$. The area of each solution peak was measured at $210 \mathrm{~nm}$. The amount of TEL and BND was calculated at each level and percentage recoveries were calculated.

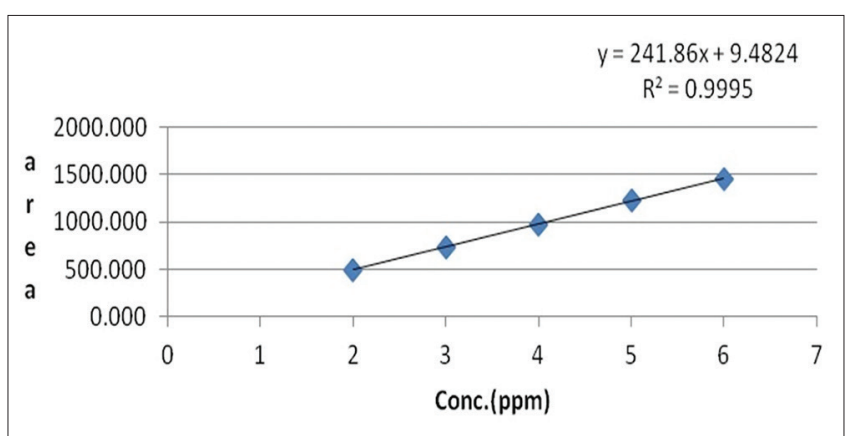

Fig. 9: Calibration curve of benidipine hydrochloride

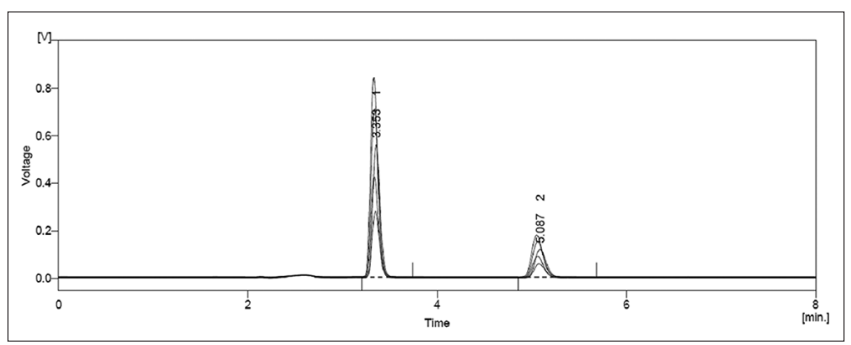

Fig. 10: Overlay chromatogram of different concentrations of binary mixtures of telmisartan and benidipine hydrochloride

Table 1: Results for system suitability test

\begin{tabular}{lll}
\hline Parameters & TEL & BEN \\
\hline Theoretical plates per column & 4361 & 7978 \\
Symmetry factor/tailing factor & 1.259 & 1.310 \\
Retention time (min) & $3.273 \mathrm{~min}$ & $4.807 \mathrm{~min}$ \\
Resolution & 7.416 & \\
\hline
\end{tabular}

TEL: Telmisartan, BEN: Benidipine hydrochloride

\section{Limit of detection (LOD) and limit of quantitation (LOQ)}

The LOD was estimated from the set of three calibration curves used to determination linearity. The LOD may be calculated as, $\mathrm{LOD}=3.3 \times$ (SD/Slope) Where, SD of Y-intercepts of 3 calibration curves. Slope $=$ Mean slope of the 3 calibration curves. The LOQ was estimated from the set of 3 calibration curves used to determine linearity. The LOQ may be calculated as, $\mathrm{LOQ}=10 \times(\mathrm{SD} / \mathrm{Slope})$ where, $\mathrm{SD}$ of Y-intercepts of three calibration curves.

\section{Robustness}

Following parameters were changed one by one and their effect was observed on system suitability for standard preparation. Flow rate of mobile phase was changed $( \pm 0.2 \mathrm{ml} / \mathrm{min}) 0.8 \mathrm{ml} / \mathrm{min}$ and $1.2 \mathrm{ml} / \mathrm{min}$, ratio of mobile phase was changed ( \pm 2 ) Buffer: Methanol (52:48) and Buffer: Methanol (48:52) and pH of buffer was changed $( \pm 0.2) \mathrm{pH} 4.2$ and $\mathrm{pH} 3.8$.

\section{Forced degradation studies[24]}

\section{Acid degradation}

Acid decomposition studies were performed by transferring $1 \mathrm{ml}$ of stock solution in to $10 \mathrm{ml}$ of volumetric flask. A volume of $2 \mathrm{ml}$ of $0.1 \mathrm{~N}$ $\mathrm{HCl}$ solutions was added and mixed well and put for $3 \mathrm{~h}$. After time period, the volume was adjusted with diluent to get $40 \mu \mathrm{g} / \mathrm{ml}$ for TEL and $4 \mu \mathrm{g} / \mathrm{ml}$ for BND.

\section{Base degradation}

Basic decomposition studies were performed by transferring $1 \mathrm{ml}$ of stock solution in to $10 \mathrm{ml}$ of volumetric flask. A volume of $2 \mathrm{ml}$ of $0.1 \mathrm{~N}$ $\mathrm{NaOH}$ solutions was added and mixed well and put for $4 \mathrm{~h}$. After time period, the volume was adjusted with diluents to get $40 \mu \mathrm{g} / \mathrm{ml}$ for TEL and $4 \mu \mathrm{g} / \mathrm{ml}$ for BND.

\section{Oxidative degradation}

Oxidation decomposition studies were performed by transferring $1 \mathrm{ml}$ of stock solution in to $10 \mathrm{ml}$ of volumetric flask. A volume of $2 \mathrm{ml}$ of $3 \%$ $\mathrm{H}_{2} \mathrm{O}_{2}$ solutions were added and mixed well and put for $3 \mathrm{~h}$. After time period, the volume was adjusted with diluents to get $40 \mu \mathrm{g} / \mathrm{ml}$ for TEL and $4 \mu \mathrm{g} / \mathrm{ml}$ for BND.

\section{Photo degradation}

Photo degradation studies were performed by transferring $1 \mathrm{ml}$ of stock solution in to $10 \mathrm{ml}$ of volumetric flask. The volumetric flask was kept under UV light in UV chamber for $18 \mathrm{~h}$. Then the volume was adjusted with diluents to get $40 \mu \mathrm{g} / \mathrm{ml}$ for TEL and $4 \mu \mathrm{g} / \mathrm{ml}$ for BND.

\section{Thermal degradation}

Thermal degradation studies were performed by transferring $1 \mathrm{ml}$ of stock solution in to $10 \mathrm{ml}$ of volumetric flask. The volumetric flask was stored in oven at $80^{\circ} \mathrm{C}$ for $6 \mathrm{~h}$. Then, the volume was adjusted with diluents to get $40 \mu \mathrm{g} / \mathrm{ml}$ for TEL and $4 \mu \mathrm{g} / \mathrm{ml}$ for BND.

Table 2: Linearity data for TEL and BND

\begin{tabular}{|c|c|c|c|c|}
\hline \multicolumn{3}{|l|}{ TEL } & \multicolumn{2}{|l|}{ BND } \\
\hline S. no & Concentration $(\mu \mathrm{g} / \mathrm{ml})$ & Area & Concentration $(\mu \mathrm{g} / \mathrm{ml})$ & Area \\
\hline 1 & 20 & 1531.035 & 2 & 489.434 \\
\hline 2 & 30 & 2305.359 & 3 & 736.534 \\
\hline 3 & 40 & 3054.430 & 4 & 975.650 \\
\hline 4 & 50 & 3857.941 & 5 & 1231.962 \\
\hline 5 & 60 & 4579.434 & 6 & 1451.016 \\
\hline \multicolumn{2}{|l|}{ S.D. } & 19.808 & 9.735 & \\
\hline \multicolumn{2}{|c|}{ Correlation coefficient } & 0.9998 & 0.9995 & \\
\hline \multicolumn{2}{|c|}{ Regression equation } & $y=76.494 x+5.8878$ & $y=241.86 x+9.4824$ & \\
\hline
\end{tabular}

TEL: Telmisartan, BEN: Benidipine hydrochloride, 


\section{RESULT AND DISCUSSION}

\section{Selection of wavelength}

Standard solution of TEL $(40 \mu \mathrm{g} / \mathrm{ml})$ and standard solution of BND $(4 \mu \mathrm{g} / \mathrm{ml})$ were scanned between 200 and $400 \mathrm{~nm}$ using UV-visible spectrophotometer. Both solutions were scanned between 200 and $400 \mathrm{~nm}$. Wavelength was selected from the overlay spectra of above solutions. Both TEL and BND show reasonably good response at $210 \mathrm{~nm}$ show in Fig. 3.

\section{Chromatographic separation}

Standard solutions of $20-60 \mu \mathrm{g} / \mathrm{ml}$ of TEL and 2-6 $\mu \mathrm{g} / \mathrm{ml}$ of BND were injected in column with $20 \mu \mathrm{l}$ microsyringe. The chromatogram was run for appropriate minutes with mobile phase Phosphate buffer (Ph4.0): Methanol (50:50). The detection was carried out at wavelength $210 \mathrm{~nm}$. The chromatogram was stopped after separation achieved completely. Data related to peak such as area, height, retention time, and resolution were recorded using software show in Fig. 4 [25].

- Column: Thermo scientific, $\left.\mathrm{C}_{18} 25 \mathrm{~cm} \times 0.46 \mathrm{~cm}\right)$ Hypersil BDS

- Mobile Phase: Phosphate buffer, pH 4.0: Methanol (50:50)

- Flow Rate: $1.0 \mathrm{ml} / \mathrm{min}$

- Detection wavelength: $210 \mathrm{~nm}$

- Runtime: 8 min

- Injection volume: $20.0 \mu \mathrm{l}$

- Diluents: Mobile Phase

\section{System suitability test}

It is an integral part of chromatographic method. These tests are used to verify that the resolution and reproducibility of the system are adequate for the analysis to be performed. System suitability tests are based on the concept that the equipment, electronics, analytical operations, and samples constitute an integral system that can be evaluated as a whole. System suitability testing provides assurance that the method will provide accurate and precise data for its intended use and all parameters are respectively showed in Table 1.

\section{Specificity}

The chromatograms of BND and TEL standards and BND and TEL sample show no interference with the chromatogram of BND and TEL blank, so the developed method is specific and show response in Figs. 5-7.

\section{Linearity and range}

The linearity for TEL and BND were assessed by analysis of combined standard solution in range of $20-60 \mu \mathrm{g} / \mathrm{ml}$ and $2-6 \mu \mathrm{g} / \mathrm{ml}$, respectively. Correlation coefficient for calibration curve TEL and BND was found to be 0.9998 and 0.9995 , respectively. This response show in Figs. 8-10 and Table 2.

\section{LOD/LOQ}

Calibration curve was repeated for five times and the SD of the intercepts was calculated. Then LOD and LOQ were calculated as follows:

$\mathrm{LOD}=3.3 * \mathrm{SD} /$ slope of calibration curve, $\mathrm{LOQ}=10 * \mathrm{SD} /$ slope of calibration curve

For TEL

$$
\begin{aligned}
\text { LOD } & =\times 3.3(\text { SD } / \text { Slope }) \\
& =\times 3.3(19.808 / 76.494) \\
& =0.855 \mu \mathrm{g} / \mathrm{ml} \\
& =0.402 \mu \mathrm{g} / \mathrm{ml}
\end{aligned}
$$

For BND

$$
\begin{aligned}
\mathrm{LOQ} & =10(\mathrm{SD} / \text { Slope }) \\
& =\times 10(19.808 / 76.494) \\
& =2.589 \mu \mathrm{g} / \mathrm{ml} \\
\mathrm{LOD} & =\times 3.3(\mathrm{SD} / \mathrm{Slope}) \\
& =\times 3.3(9.735 / 241.86) \\
& =0.133 \mu \mathrm{g} / \mathrm{ml} \\
\mathrm{LOQ} & =\times 10(\mathrm{SD} / \mathrm{Slope}) \\
& =\times 10(9.735 / 241.86)
\end{aligned}
$$

\section{Precision}

Repeatability

The data for repeatability of peak area measurement for TEL and BND based on six measurements of same solution of TEL and BND are summazed in Table 3. The percentage RSD for TEL and BND was found to be 0.671 and 0.509 , respectively

\section{Intraday precision}

The data for intraday precision for TEL and BND are shown in Table 4. The percentage RSD for intraday precision was found to be 0.916-1.044 for TEL and 0.649-1.331 for BND

\section{Interday precision}

The data for intraday precision for TEL and BND are shown in Table 5. The percentage RSD for interday precision was found to be 0.622-0.982 for TEL and 0.807-1.690 for BND.

\section{Accuracy}

Accuracy of the method was confirmed by recovery study from marketed formulation at three level of standard addition. The results are shown in Tables 6 and 7. Percentage recovery for TEL was $99.258 \%-101.413$ $\%$, while for BND, it was found to be in range of $98.982 \%-101.506 \%$

\section{Robustness}

The effect of changes was found to be within the acceptance criteria as shown in Tables 8 and 9.The percentage RSD should be $<2 \%$.

\section{Stability indicating method}

Stability of both drugs are studied utilizing different parameter. In this study, the area of standard for stability and degradation of sample and standard were compare. The standard area of BND and TEL is 649.883 and 2649.948, respectively. Result shows BND has highest degradation in oxidation and thermal as compare to others. TEL shows highest degradation in oxidation and basic environment. The peaks of all parameters are given in Fig 11-31. The percent degradation of all parameters is given below in Tables 10 and 11 [26].

Table 3: Repeatability data for TEL and BND

\begin{tabular}{lll}
\hline S. no. & Area & \\
\cline { 2 - 3 } & TEL Conc. $\mathbf{4 0} \boldsymbol{\mu g} / \mathbf{m l}$ & BND Conc. $\mathbf{4} \boldsymbol{\mu g} / \mathbf{m l}$ \\
\hline 1 & 3072.532 & 981.403 \\
2 & 3051.079 & 973.610 \\
3 & 3057.200 & 978.335 \\
4 & 3032.814 & 968.540 \\
5 & 3093.458 & 980.913 \\
6 & 3065.703 & 979.004 \\
Mean \pm SD & $3062.131 \pm 20.534$ & $976.9668 \pm 4.971$ \\
\%RSD & 0.671 & 0.509 \\
\hline
\end{tabular}

RSD: Relative standard deviation, SD: Standard deviation, TEL: Telmisartan, BEN: Benidipine hydrochloride

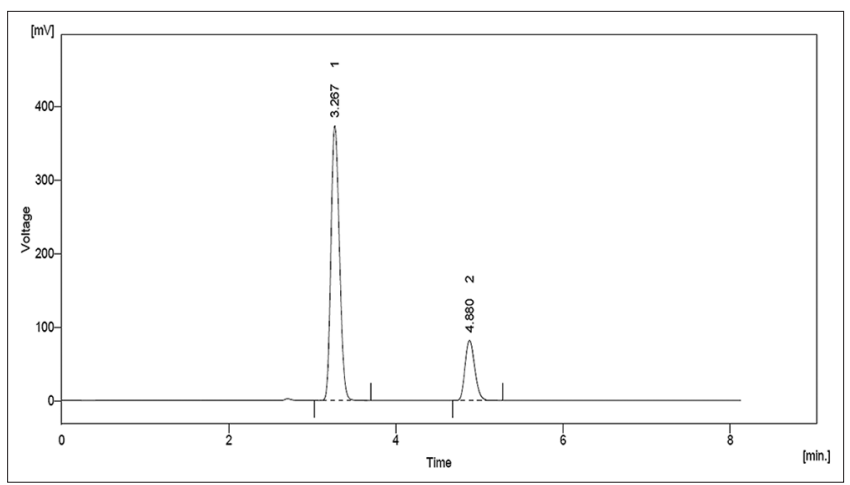

Fig. 11: Standard for stability 
Table 4: Intraday precision data for estimation of TEL and BND

\begin{tabular}{|c|c|c|c|c|c|c|c|c|}
\hline \multicolumn{5}{|l|}{ TEL } & \multicolumn{4}{|l|}{ BND } \\
\hline S. no. & Conc. $(\mu \mathrm{g} / \mathrm{ml})$ & Area & Mean \pm SD & $\%$ RSD & Conc. $(\mu \mathrm{g} / \mathrm{ml})$ & Area & Mean \pm SD & \% RSD \\
\hline \multirow[t]{3}{*}{1} & 20 & 1537.16 & $1535.5 \pm 16.029$ & 1.044 & 2 & 491.406 & $490.0 \pm 6.526$ & 1.331 \\
\hline & 20 & 1518.737 & & & 2 & 482.886 & & \\
\hline & 20 & 1550.67 & & & 2 & 495.709 & & \\
\hline \multirow[t]{3}{*}{2} & 40 & 3051.411 & $3049.9 \pm 29.626$ & 0.971 & 4 & 974.667 & $975.8 \pm 6.973$ & 0.714 \\
\hline & 40 & 3078.832 & & & 4 & 983.395 & & \\
\hline & 40 & 3019.634 & & & 4 & 969.61 & & \\
\hline \multirow[t]{3}{*}{3} & 60 & 4606.989 & $4643.6 \pm 42.561$ & 0.916 & 6 & 1465.598 & $1476.5 \pm 9.582$ & 0.649 \\
\hline & 60 & 4633.685 & & & 6 & 1480.366 & & \\
\hline & 60 & 4690.335 & & & 6 & 1483.561 & & \\
\hline
\end{tabular}

RSD: Relative standard deviation, SD: Standard deviation, TEL: Telmisartan, BEN: Benidipine hydrochloride

Table 5: Interday precision data for estimation of TEL and BND

\begin{tabular}{|c|c|c|c|c|c|c|c|c|}
\hline \multicolumn{5}{|l|}{ TEL } & \multicolumn{4}{|l|}{ BND } \\
\hline Sr. No. & Conc. $(\mu \mathrm{g} / \mathrm{ml})$ & Area & Mean \pm SD & \% RSD & Conc. $(\mu \mathrm{g} / \mathrm{ml})$ & Area & Mean \pm SD & $\%$ RSD \\
\hline \multirow[t]{2}{*}{1} & 20 & 1529.54 & $1521.94 \pm 9.47$ & 0.622 & 2 & 488.945 & $484.85 \pm 5.830$ & 1.202 \\
\hline & 20 & 1511.33 & & & 2 & 478.182 & & \\
\hline \multirow[t]{3}{*}{2} & 40 & 3063.62 & $3033.11 \pm 29.78$ & 0.982 & 4 & 978.548 & $970.70 \pm 7.834$ & 0.807 \\
\hline & 40 & 3031.06 & & & 4 & 970.676 & & \\
\hline & 40 & 3004.11 & & & 4 & 962.88 & & \\
\hline \multirow[t]{3}{*}{3} & 60 & 4597.87 & $4555.17 \pm 41.21$ & 0.904 & 6 & 1464.615 & $1439.66 \pm 34.331$ & 1.690 \\
\hline & 60 & 4552.01 & & & 6 & 1416.004 & & \\
\hline & 60 & 4515.63 & & & 6 & 1438.379 & & \\
\hline
\end{tabular}

RSD: Relative standard deviation, SD: Standard deviation, TEL: Telmisartan, BEN: Benidipine hydrochloride

Table 6: Accuracy data for TEL

\begin{tabular}{|c|c|c|c|c|c|c|c|c|}
\hline S. no & Conc. Level (\%) & $\begin{array}{l}\text { Sample } \\
\text { amount }(\mu \mathrm{g} / \mathrm{ml})\end{array}$ & $\begin{array}{l}\text { Amount } \\
\text { added }(\mu \mathrm{g} / \mathrm{ml})\end{array}$ & $\begin{array}{l}\text { Amount } \\
\text { recovered }(\mu \mathrm{g} / \mathrm{ml})\end{array}$ & $\%$ recovery & $\%$ Mean recovery & SD & $\%$ RSD \\
\hline 1 & 80 & 20 & 16 & 16.093 & 100.582 & 99.258 & 1.168 & 1.177 \\
\hline 2 & & 20 & 16 & 15.740 & 98.374 & & & \\
\hline 3 & & 20 & 16 & 15.811 & 98.818 & & & \\
\hline 4 & 100 & 20 & 20 & 20.190 & 100.951 & 101.413 & 0.429 & 0.423 \\
\hline 5 & & 20 & 20 & 20.360 & 101.799 & & & \\
\hline 6 & & 20 & 20 & 20.298 & 101.490 & & & \\
\hline 8 & & 20 & 24 & 24.133 & 100.553 & & & \\
\hline 9 & & 20 & 24 & 24.307 & 101.281 & & & \\
\hline
\end{tabular}

RSD: Relative standard deviation, SD: Standard deviation, TEL: Telmisartan, BEN: Benidipine hydrochloride

Table 7: Accuracy data for BND

\begin{tabular}{|c|c|c|c|c|c|c|c|c|}
\hline S no. & $\begin{array}{l}\text { Conc. } \\
\text { level (\%) }\end{array}$ & $\begin{array}{l}\text { Sample } \\
\text { amount }\end{array}$ & Amount added & Amount recovered $(\mu \mathrm{g} / \mathrm{ml})$ & $\%$ recovery & $\%$ Mean recovery & SD & $\%$ RSD \\
\hline 1 & 80 & 2 & 1.6 & 1.609 & 100.535 & 98.982 & 1.398 & 1.413 \\
\hline 2 & & 2 & 1.6 & 1.569 & 98.075 & & & \\
\hline 3 & & 2 & 1.6 & 1.570 & 98.154 & & & \\
\hline 4 & 100 & 2 & 2 & 2.031 & 101.560 & 101.506 & 0.613 & 0.604 \\
\hline 5 & & 2 & 2 & 2.017 & 100.868 & & & \\
\hline 6 & & 2 & 2 & 2.042 & 102.090 & & & \\
\hline 8 & & 2 & 2.4 & 2.369 & 98.723 & & & \\
\hline 9 & & 2 & 2.4 & 2.425 & 101.030 & & & \\
\hline
\end{tabular}

RSD: Relative standard deviation, SD: Standard deviation, TEL: Telmisartan, BEN: Benidipine hydrochloride

\section{CONCLUSION}

The combined dosage form of benidipine $\mathrm{HCl}$ and TEL are used in the treatment of hypertension. Various methods are reported for the analysis of individual drug and in combination with other drugs but no HPLC method reported for these two drugs in combined dosage form. Therefore, a novel RP- HPLC method has been developed for the simultaneous estimation of benidipine $\mathrm{HCl}$ and
TEL in marketed formulations. The optimized chromatogram was run for appropriate minutes with mobile phase phosphate buffer (pH 4.0): Methanol (50:50). Data related to peak such as area, height, retention time, resolution, etc., were recorded using software. Thermo scientific, $\mathrm{C}_{18}(25 \mathrm{~cm} \times 0.46 \mathrm{~cm})$ Hypersil BDS, Mobile Phase Phosphate buffer, $\mathrm{pH}$ 4.0: Methanol (50:50) with flow rate $1.0 \mathrm{ml} / \mathrm{min}$ and Runtime: $8 \mathrm{~min}$ injection volume of $20.0 \mu$. The detection was carried 
Table 8: Robustness data for TEL

\begin{tabular}{|c|c|c|c|c|c|c|}
\hline Sr. No. & $\begin{array}{l}\text { Area at Flow } \\
\text { rate }(-0.2 \mathrm{ml} / \mathrm{min})\end{array}$ & $\begin{array}{l}\text { Area at Flow rate } \\
(+0.2 \mathrm{ml} / \mathrm{min})\end{array}$ & $\begin{array}{l}\text { Area at Mobile } \\
\text { phase }(-2)\end{array}$ & $\begin{array}{l}\text { Area at Mobile } \\
\text { phase }(+2)\end{array}$ & $\begin{array}{l}\text { Area at } \\
\text { pH }(-0.2)\end{array}$ & $\begin{array}{l}\text { Area at } \\
\text { pH }(+0.2)\end{array}$ \\
\hline 1 & 3127.605 & 3038.758 & 3136.936 & 3060.068 & 3144.050 & 3081.693 \\
\hline 2 & 3096.317 & 3047.785 & 3168.318 & 3054.041 & 3152.045 & 3103.322 \\
\hline 3 & 3148.884 & 3023.195 & 3136.665 & 3072.257 & 3129.609 & 3109.673 \\
\hline Avg. Area & 3124.269 & 3036.579 & 3147.306 & 3062.122 & 3141.901 & 3098.229 \\
\hline S.D. & 26.442 & 12.439 & 18.197 & 9.280 & 11.371 & 14.669 \\
\hline$\%$ RSD & 0.846 & 0.410 & 0.578 & 0.303 & 0.362 & 0.473 \\
\hline
\end{tabular}

RSD: Relative standard deviation, SD: Standard deviation, TEL: Telmisartan

Table 9: Robustness data for BND

\begin{tabular}{|c|c|c|c|c|c|c|}
\hline S. no. & $\begin{array}{l}\text { Area at Flow } \\
\text { rate }(-0.2 \mathrm{ml} / \mathrm{min})\end{array}$ & $\begin{array}{l}\text { Area at Flow rate } \\
(+0.2 \mathrm{ml} / \mathrm{min})\end{array}$ & $\begin{array}{l}\text { Area at Mobile } \\
\text { phase }(-2)\end{array}$ & $\begin{array}{l}\text { Area at Mobile } \\
\text { phase }(+2)\end{array}$ & $\begin{array}{l}\text { Area at } \\
\text { pH }(-0.2)\end{array}$ & $\begin{array}{l}\text { Area at } \\
\mathrm{pH}(+0.2)\end{array}$ \\
\hline 1 & 998.946 & 970.575 & 1001.913 & 977.383 & 1004.105 & 984.289 \\
\hline 2 & 988.943 & 977.370 & 996.071 & 975.437 & 997.674 & 991.177 \\
\hline 3 & 990.868 & 965.593 & 1001.830 & 984.252 & 1007.707 & 998.113 \\
\hline Avg. Area & 992.919 & 971.179 & 999.938 & 979.024 & 1003.162 & 991.193 \\
\hline S.D. & 5.308 & 5.912 & 3.349 & 4.631 & 5.083 & 6.912 \\
\hline$\%$ RSD & 0.535 & 0.609 & 0.507 & 0.697 & 0.335 & 0.473 \\
\hline
\end{tabular}

RSD: Relative standard deviation, SD: Standard deviation, BEN: Benidipine hydrochloride

Table 10: Degradation of BND

\begin{tabular}{|c|c|c|c|c|}
\hline Condition & Area of standard & \% degradation & Area of sample & $\%$ degradation \\
\hline Acid & 559.499 & 13.908 & 543.250 & 16.408 \\
\hline Base & 577.202 & 11.184 & 570.394 & 12.231 \\
\hline Thermal & 529.643 & 18.502 & 547.393 & 15.771 \\
\hline Oxidation & 515.387 & 20.695 & 498.924 & 23.229 \\
\hline Photo & 570.778 & 12.172 & 574.950 & 11.530 \\
\hline
\end{tabular}

BEN: Benidipine hydrochloride

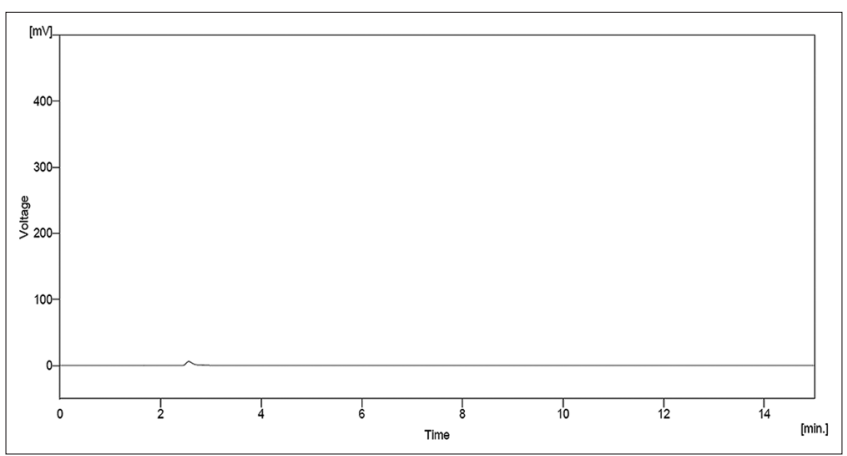

Fig. 12: Acid degradation blank

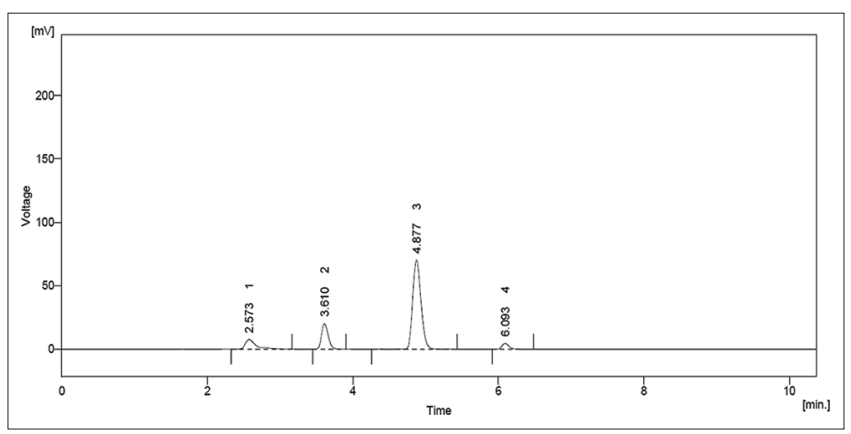

Fig. 13: Acid degradation of benidipine hydrochloride

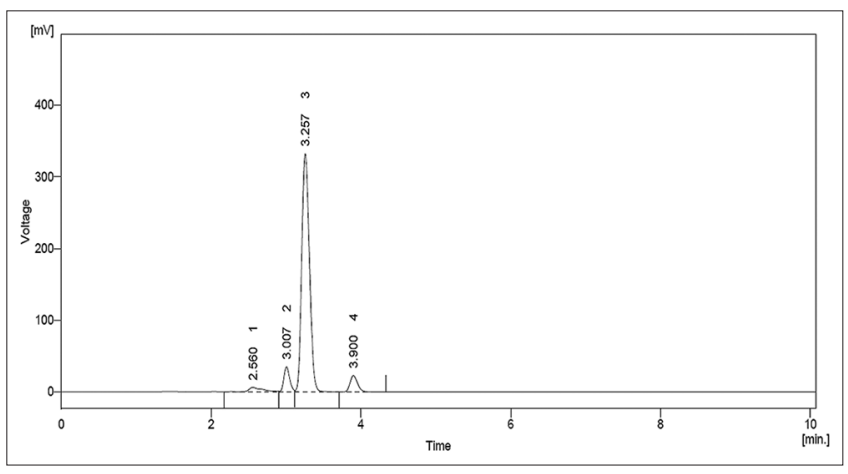

Fig. 14: Acid degradation of telmisartan

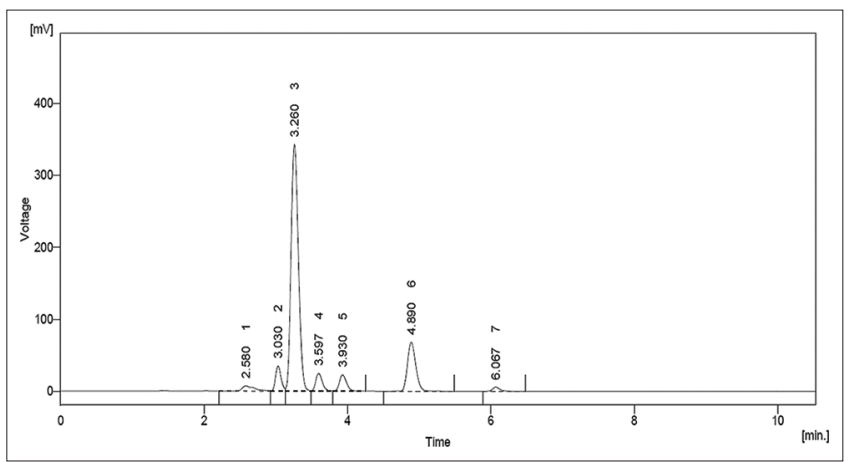

Fig. 15: Acid degradation sample 
Table 11: Degradation of TEL

\begin{tabular}{llll}
\hline Condition & Area of standard & \% degradation & Area of sample \\
\hline Acid & 2349.042 & 11.355 & 2327.872 \\
Base & 2271.527 & 14.280 & 2299.061 \\
Thermal & 2289.502 & 13.602 & 2341.262 \\
Oxidation & 2058.846 & 22.306 & 2236.532 \\
Photo & 2278.141 & 14.031 & 2357.661 \\
\hline
\end{tabular}

TEL: Telmisartan

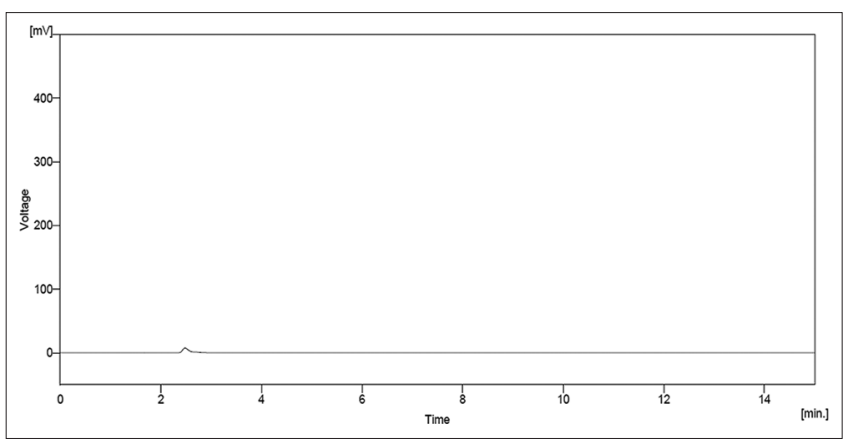

Fig. 16: Base degradation blank

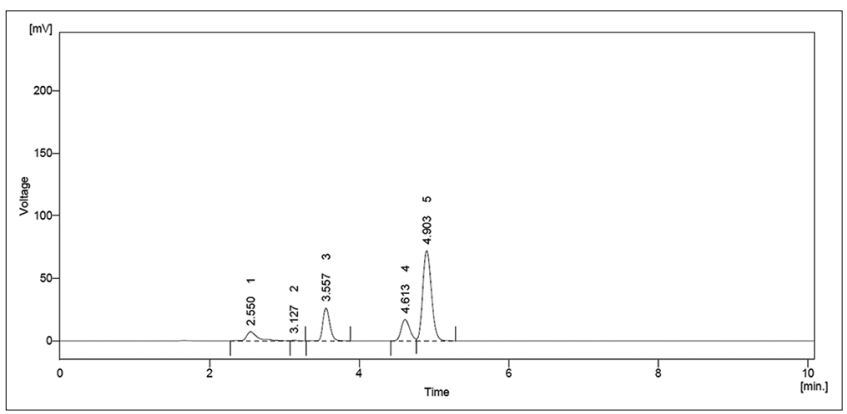

Fig. 17: Base degradation of benidipine hydrochloride

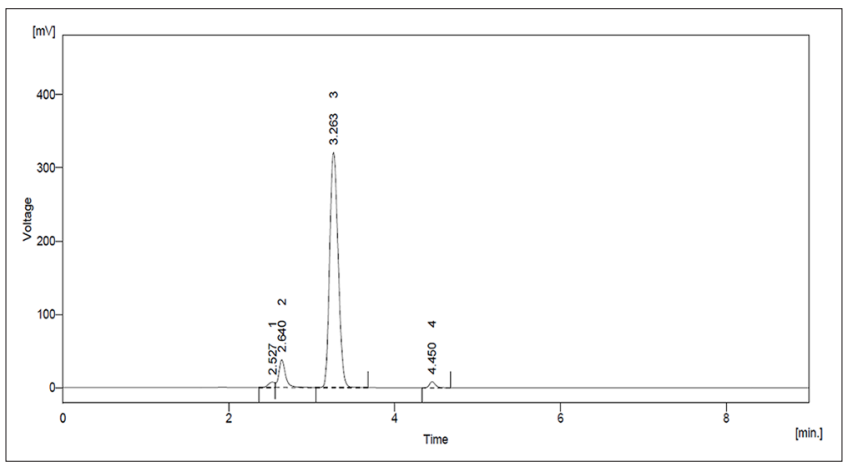

Fig. 18: Base degradation of telmisartan

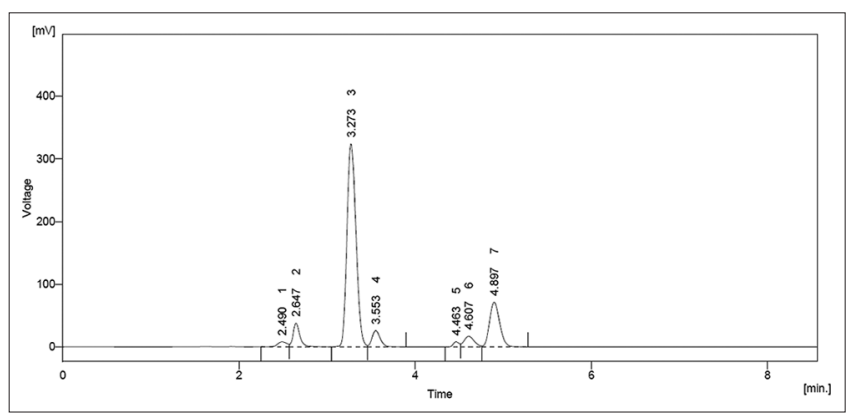

Fig. 19: Base degradation sample

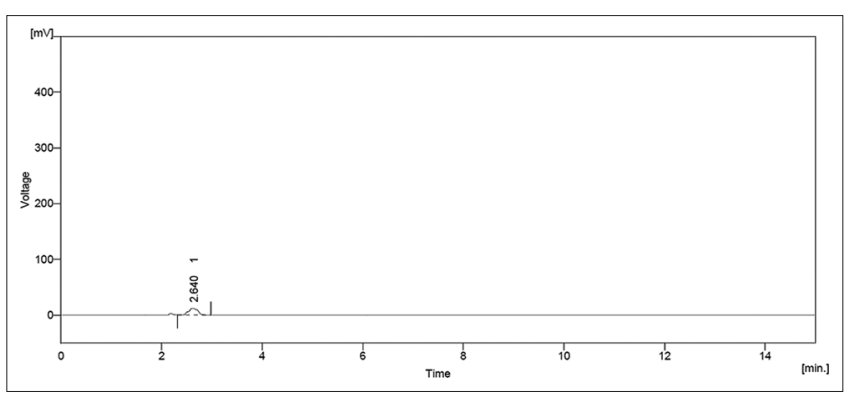

Fig. 20: Oxidation degradation blank

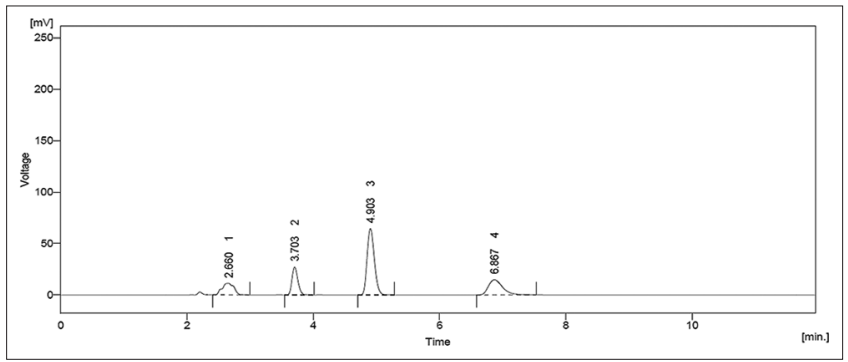

Fig. 21: Oxidation degradation of benidipine hydrochloride

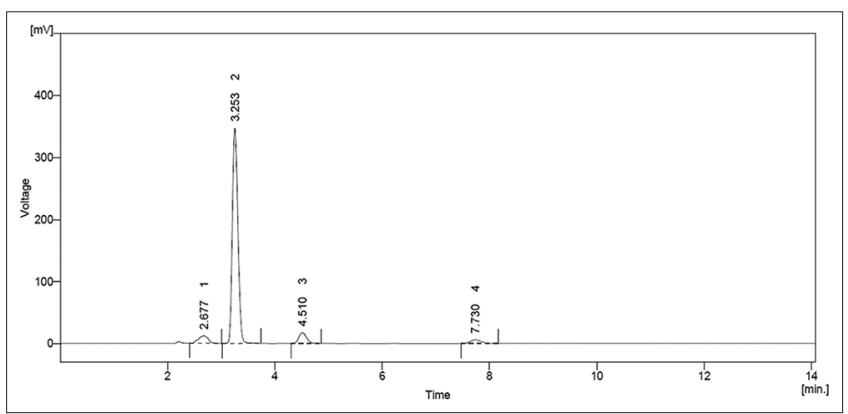

Fig. 22: Oxidation degradation of telmisartan

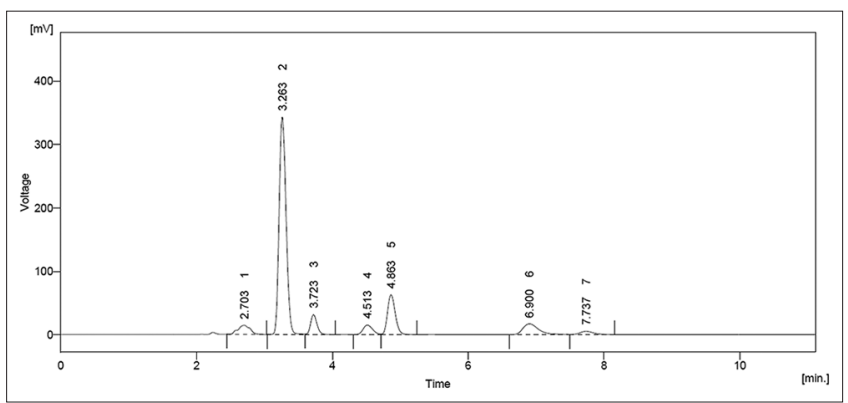

Fig. 23: Oxidation degradation sample 


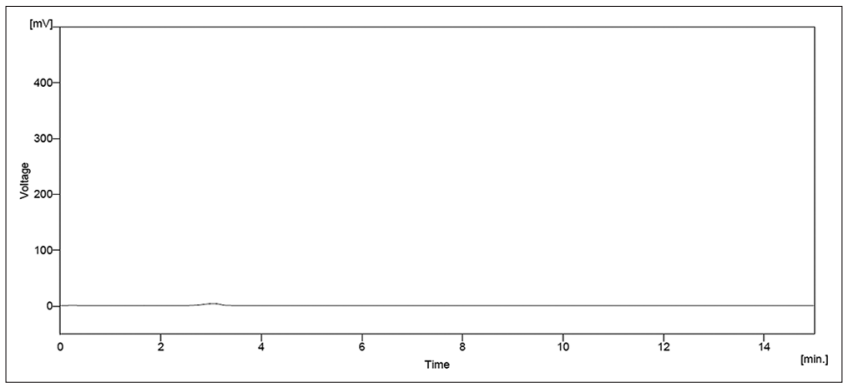

Fig. 24: Photodegradation blank

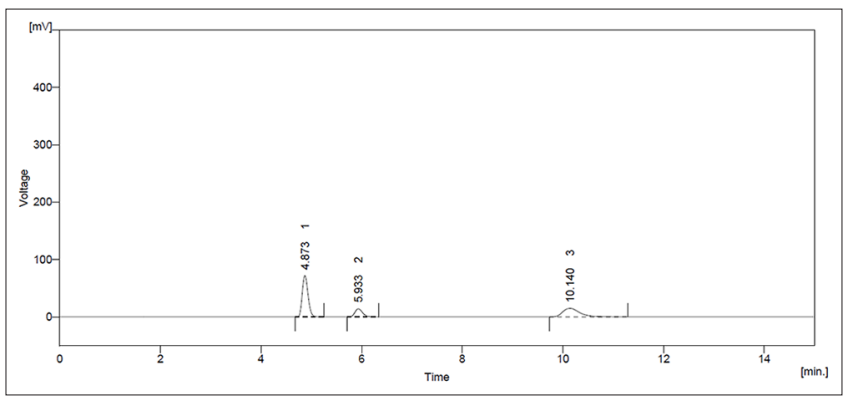

Fig. 25: Photodegradation of benidipine hydrochloride

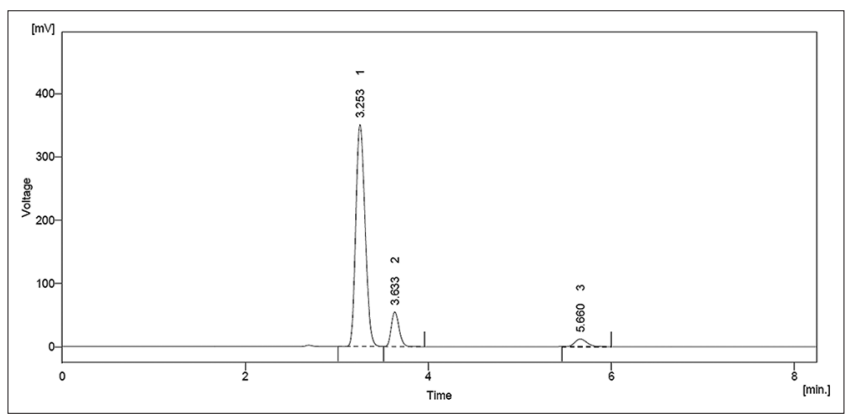

Fig. 26: Photodegradation of telmisartan

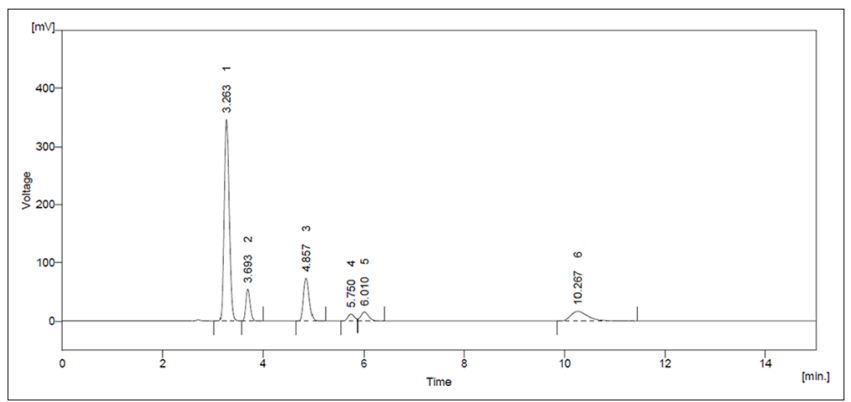

Fig. 27: Photodegradation sample

out at wavelength $210 \mathrm{~nm}$. It was found to be simple, precise and accurate. In this stability indicating RP-HPLC methods were developed by degradation of sample and compared with standard. The percentage RSD was also $<2 \%$ showing high degree of precision of the proposed method. The proposed method can be used for routine analysis of benidipine $\mathrm{HCl}$ and TEL in combined dosage form. It can be also used in the quality control in bulk manufacturing.

\section{ACKNOWLEDGMENT}

The authors are thankful to president JIIU's G. M. Vastanvi and Principal for their encouragement and support. We also wish to thanks

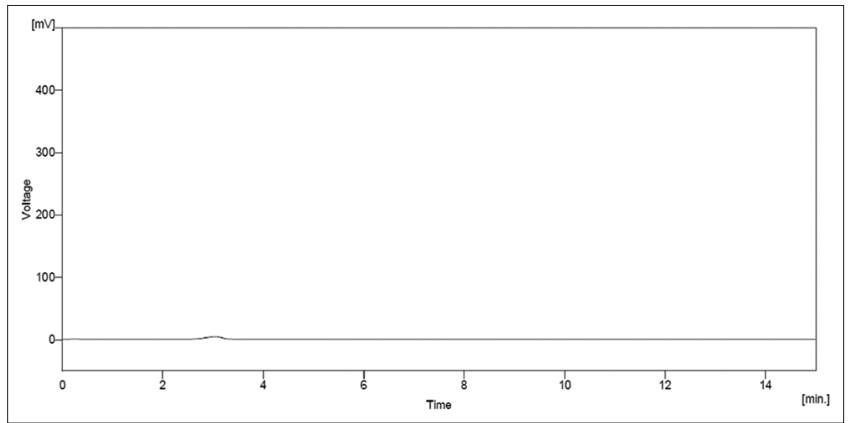

Fig. 28: Thermal degradation blank

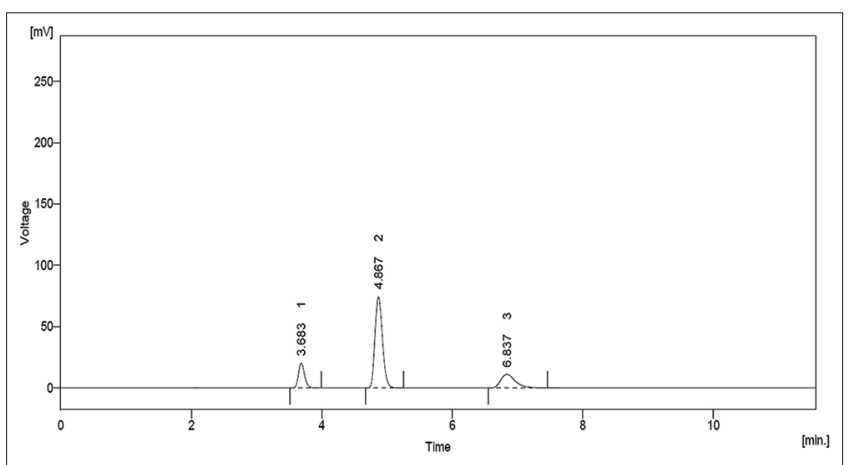

Fig. 29: Thermal degradation of benidipine hydrochloride

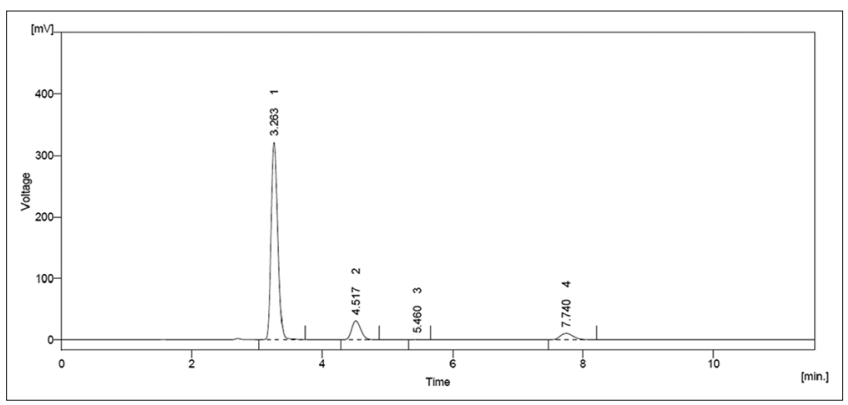

Fig. 30: Thermal degradation of telmisartan

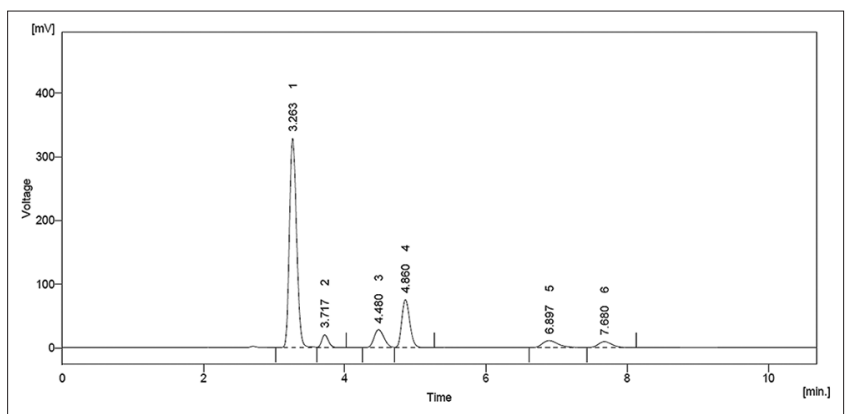

Fig. 31: Thermal degradation sample

to Mr. Ketan Patel, Molecule Laboratory and Yash Pharmaceutical Ahmadabad, Gujarat.

\section{REFERENCES}

1. Drug profile for Telmisartan. August-2017. Available from: http:// www.drugbank.ca/drugs/DB00966. [Last accessed on 2017 Nov 20].

2. The Indian Pharmacopoeia Commission Ghaziabad. Indian Pharmacopoeia. Vol. III. Ghaziabad: The Indian Pharmacopoeia Commission Ghaziabad; 2010. p. 2186-7. 
3. Drug Profile for Benidipine $\mathrm{HCl}$, August-2017. Available from: http:// www.drugbank.ca/drugs/DB09231. [Last accessed on 2017 Nov 20].

4. Drug Profile for Benidipine $\mathrm{HCl}$, August-2017. Available from: https://www.aksci.com/item detail.php?cat=K668. [Last accessed on 2017 Nov 20].

5. Kumar GV, Murthy TE, Rao KS. Validated RP-HPLC method for the estimation of telmisartan in serum samples. Int J Res Pharm Chem 2011;1:703-6.

6. Rao JS, Vijyasree V, Palavan C. A validated RP-HPLC method for the estimation of telmisartan in tablet dosage forms. Am J Pharm Tech Res 2013;3:763-9

7. Rao MV, Nagendra AV, Sivanadh M, Rao GV. Validated RP-HPLC method for the estimation of telmisartan in tablet formulation. Bull Pharm Res 2012;2:50-5.

8. Wankhede SB, Tajane MR, Gupta KR. RP-HPLC method for simultaneous estimation of telmisartan and hydrochlorothiazide in tablet dosage form. Ind J Pharm Sci 2007;69:298-300.

9. Rupareliya RH, Joshi HS. Stability Indicating Simultaneous Validation of Telmisartan and Cilnidipine with Forced Degradation behavior Study by RP-HPLC in Tablet Dosage Form. London, United Kingdom: Hindawi Publishing Corporation ISRN Chromatography; 2003. p. 1-6.

10. Patel AR, Chandrul KK. Method development, validation and stability study for simultaneous estimation of telmisartan and indapamide by reverse phase-high performance liquid chromatography in pure and marketed formulation. Int J Pharm Bio Res 2011;2:4-16.

11. Jat RK, Sharma S, Chippa RC, Singh R, quantitative estimation of telmisartan in bulk drug and tablets by UV spectroscopy. Int J Drug Res Tech 2012;2:268-72.

12. Jaithalia R, Chauhan RK, Chauhan C, Gupta A. Development of UV spectrophotometer method and it's validation for estimation of telmisartan as API and in pharmaceutical dosage form. Int J Res Pharm 2011;2:1816-8

13. Patel K, Patel A, Dave J. Absorbance correction method for estimation of telmisartan and metoprolol succinate in combined tablet dosage forms. Pharm Methods 2012;3:106-11.

14. Tamboli AM, Jamadar MJ, Khan AI, Munure JY.UV-Spectrophotometric determination of telmisartan and hydrochlorothiazide in combined tablet dosage form using simultaneous equation method. Int J Adv Pharm Sci 2014:4:18-22.
15. Atici EB, Karliga B. Identification, synthesis and characterization of process related impurities of benidipine hydrochloride, stress-testing/ stability studies and HPLC/UPLC method validations. J Pharm Anal 2015;5:265-8.

16. Buridi K, Shantiswarup L, Raghubabu K. Validated visible Spectrophotometric methods development for the determination of benidipine hydrochloride based on complex and internal salt formation reactions. Int J Inst Pharm Life Sci 2012;2:25-33.

17. Singhvi I, Chaturvedi SC. Spectrophotometric method for estimation of amlodipine basylate and benidipine $\mathrm{HCl}$ from tablet. Ind J Pharm Sci 1999;61:190-1.

18. Dong WM. Modern HPLC for Practicing Scientists. USA: A WileyInter Science Publication; 2006. p. 1-9.

19. Krull SM. Developing and validating stability-indicating methods. LCGC North Am 2005;23:586-93.

20. Patel BA, Captain AD. RP-HPLC method for simultaneous estimation of telmisartan and hydrochlorothiazide in API and dosage form. Indo. Am J Pharm Res 2014;4:3031-8.

21. Snyder LR, Kirkland JJ, Glajch LJ. Introduction to Modern Liquid Chromatography. $2^{\text {nd }}$ ed. New York, USA: A Wiley-Inter Science Publication; 1997. p. 5-42.

22. Patel JM, Dhingani JP, Garala KC, Raval MK. Development and validation of bioanalytical HPLC method for estimation of telmisartan in rat plasma: Application toc-pharmacokinetic studies. J Pharm Sci 2012;11:121-7.

23. Patel BA, Captain AD. Development and validation of RP-HPLC method for estimation of telmisartan in bulk and formulation using fluorescence detector. J Bio Med Pharm Res 2014;3:44-8.

24. Ruan J, Tattersall P, Lozano R, Shah P. The role of forced degradation studies in stability indicating HPLC method development. Am Pharm Rev 2006;9:46-53.

25. Chavhan V, Lawande R, Salunke J, Ghante M, Jagtap S. UV spectrophotometric method development and validation for telmisartan in bulk and tablet dosage form. Asian J Pharm Clin Res 2013;6:19-21.

26. Kumar MS, Jupally VR. Development and validation of a stability indicating Rp-Hplc method for simultaneous determination of telmisartan and amlodipine in combined dosage form. Asian J Pharm Clin Res 2014;7:32-35. 